\title{
Tekniikan Waiheita avoimena verkkolehtenä
}

Mikä on suomalaisen teknologian historian tutkimuksen merkitys yhteiskunnalle? Suomi on korkean ja monipuolisen teknologian maa, jossa tehdään innovaatioita ja ylläpidetään vuosien saatossa pitkälle kehitettyä infrastruktuuria. Teknologian maata ei kuitenkaan ole rakennettu hetkessä, vaan se on lukuisten sukupolvien työn tulosta. Teknologian historian tutkijajoukko on myös moninainen. Useimmat lehteen kirjoittavat ovat löytäneet kotinsa Suomen historian, yhteiskuntahistorian, kulttuurihistorian, taloushistorian, yrityshistorian tai tekniikan tutkimuksen kentiltä. Tieteellisen tutkimuksen perusrahoitukseen kohdistuneet leikkaukset pakottavat yliopistot keskittymään käytössä olevia mittareita parhaiten vastaaviin aloihin, eikä pieni, pitkin maata hajaantunut erikoisala useinkaan näyttäydy tällaisena. Epäsuhta on huomattava. Teknologian maa katsoo tulevaan, mutta muistaako se oman historiansa? Vähemmästä Tekniikan Waiheita -lehden pitämiseksi olemassa ei ole kyse. Verkkolehti on askel tulevaan mutta tie on pitkä ja vaatii vielä paljon työtä, apua ja vapaaehtoisten toimijoiden ponnistuksia.

Tässä numerossa yhdistyvät uusin tieteellinen tutkimus, tekniikan ja teollisuuden historian kulttuuriperinnön tallennustyö, sekä molempien välittäminen kirjallisesti ja museonäyttelyissä. Kaikki nämä ovat edelleen lehden keskeisiä teemoja vaikka julkaisutapa ja ulkoasu ovatkin muuttuneet.

Syynä muutoksiin ovat tieteen tarpeet, julkaisutoiminnan ympäristön murros sekä tutkimuksen saavutettavuus. Lehden vanhassa ulkoasussa ei todellakaan ollut mitään vikaa. Se vain oli suunniteltu painettuna luettavaksi, eikä näin enää istunut parhaimmalla mahdollisella tavalla verkkojulkaisuun. Nyt kun lehteä julkaistaan suoraan Journal.fi -palvelussa, on digitaalisen julkaisun hyödyt ja haitat otettava huomioon. Tämän takia viittaustapaa artikkeleissa on uudistettu paremmin kansainvälisiä käytäntöjä vastaaviksi. Verkkolehdessä jokainen artikkeli saa pysyväistunnisteen, joka ei muutu vaikka kaikki muu muuttuisi. Tällä DOI-tunnisteella jokainen kirjoitus on jatkossa aina löydettävissä. Jotta luettavuus olisi parempi sähköisillä välineillä, on kaksipalstaisesta taitosta myös luovuttu. Toisaalta digitaalinen julkaisu tarjoaa meille mahdollisuuden hyödyntää värejä ja kuvia aivan uudella tavalla.

Numeron avaavassa englanninkielisessä tutkimusartikkelissa Between Technological Nostalgia and Engineering Imperialism: Digital History Readings of China in the Finnish Technoindustrial Public Sphere 1880-1912 Mats Fridlund ja Matti La Mela valottavat digitaalisen historiantutkimuksen tulevaisuutta katsomalla samalla suomalaisten tekniikan alan julkaisujen historiaan. Millaisena Kiina näyttäytyi suomalaisissa insinöörilehtien kirjoituksissa 1800- ja 1900-lukujen taitteessa, ja miten suomalaiset teknologian ammattilaiset toimivat Kiinassa?

Pitkässä katsauksessa Konepajakulttuuri talteen - pelastusdokumentointia ja historian keruuta Hyvinkään lakkeautettavalla konepajalla Suomen Rautatiemuseon näyttelypäällikkö Marina Bergström valottaa Valtion Rautateiden käytöstä poistuvan Hyvinkään varikon historian dokumentointihanketta, jonka rikas sanallinen ja kuvallinen sato tulee palvelemaan Suomen rautateiden ja teollisen kulttuuriympäristön tutkimusta pitkään.

Suomalaisen suurteollisuuden historiaa käsittelee myös tekniikan tohtori Saara Matalan väitösluento, lectio praecursoria The Finlandisation of Shipbuilding: Industrialisation, the State, and the Disintegration of a Cold War Shipbuilding System. 19.1.2019 Aalto-yliopiston insinööritieteiden korkeakoulun teollistumisen historiasta väitellyt tohtori Matala avaa esitelmässään suomalaisen laivanrakennusteollisuuden suhdetta valtioon ja merkitystä idänkaupalle kylmän sodan viimeisinä vuosikymmeninä. Merkittävän teollisuudenalan historiasta on julkaistu 
viime vuosina useita tutkimuksia, ja idänkaupan monisyisen historian tutkimus on samalla saanut uutta puhtia ja uusia ideoita.

Laivoja ja junia vauhdikkaampaa liikenneteknologiaa esittelee Maiju Wuokko näyttelyarviossaan Ducati-moottoripyörätehtaan museosta Bolognan Borgo Panigalen kaupunginosassa.

Tekniikan Historian Seuran vuoden 2017 artikkelipalkinto jaettiin syyskokouksessa joulukuussa 2018. Petri Saarikosken oivallinen artikkeli Ojennat kätesi ja joku tarttuu siihen - kokemuksia ja muistoja kotimaisen BBS-harrastuksen valtakaudelta on pian myös verkossa luettavissa, kun vuosien 2015-2018 numerot lisätään lehden avoimeen arkistoon.

Vuoden 2019 ensimmäinen numero ilmestyy myöhässä. Suunniteltujen muutosten lisäksi toimitusta kohtasi koko joukko yllättäviä, valitettavia ja surullisiakin tapahtumia, jotka veivät valitettavasta oman aikansa. Pahoittelemme viivästystä.

Antoisia lukuhetkiä!

\section{Aaro Sahari}

Päätoimittaja 